\title{
The melanocyte inducing factor MITF is stably expressed in cell lines from human clear cell sarcoma
}

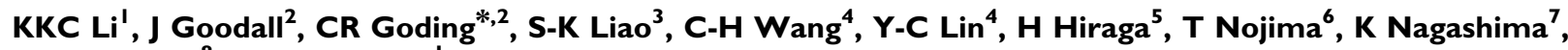 \\ K-L Schaefer ${ }^{8}$ and KAW Lee'
}

'Department of Biology, HK University of Science \& Technology, Kowloon, HK, China; ${ }^{2}$ Marie Curie Research Institute, The Chart, Oxted, Surrey RH8 OTL, UK; ${ }^{3}$ Graduate Institute of Clinical Medicine, Chang Gung University, Kweishan, Taoyuan 333, Taiwan; ${ }^{4}$ Division of Hematology/Oncology, Department of Internal Medicine, Chang Gung Memorial Hospital, Kweishan, Taoyuan 333, Taiwan; ${ }^{5}$ Division of Orthopaedics, Department of Clinical Research,

National Sapporo Hospital, Sapporo 003-0804, Japan; ${ }^{6}$ Department of Clinical Pathology, Kanazawa Medical University, Ishikawa 920-0293, Japan; ${ }^{7}$ Department of Pathology, Hokkaido University School of Medicine, N-I 5, W-7, Kita-ku, Sapporo, Japan; ${ }^{8}$ Institute of Pathology, Heinrich-Heine-

University, Dusseldorf, Germany

Clear cell sarcoma (CCS) is associated with the EWS/ATFI oncogene that is created by chromosomal fusion of the Ewings Sarcoma oncogene (EWS) and the cellular transcription factor ATFI. The melanocytic character of CCS suggests that the microphthalmiaassociated transcription factor (Mitf), a major inducer of melanocytic differentiation, may be miss-expressed in CCS. Accordingly, we show that the mRNA and protein of the melanocyte-specific isoform of Mitf (Mitf-M) are present in several cultured CCS cell lines (Su-ccs-I, DTCI, Kao, MST-I, MST-2 and MST-3). The above cell lines thus provide a valuable experimental resource for examining the role of Mitf-M in both CCS and melanocyte differentiation. Melanocyte-specific expression of Mitf-M is achieved via an ATFdependent melanocyte-specific cAMP-response element in the Mitf-M promoter, and expression of Mitf-M in CCS cells suggests that EWS/ATFI (a potent and promiscuous activator of cAMP-inducible promoters) may activate the Mitf-M promoter. Surprisingly, however, the Mitf-M promoter is not activated by EWS/ATFI in transient assays employing CCS cells, melanocytes or nonmelanocytic cells. Thus, our results indicate that Mitf-M promoter activation may require an appropriate chromosomal context in CCS cells or alternatively that the Mitf-M promoter is not directly activated by EWS/ATFI.

British Journal of Cancer (2003) 89, 1072-1078. doi:I0.1038/sj.bjc.66012I2 www.bjcancer.com

(c) 2003 Cancer Research UK

Keywords: EWS/ATFI; MITF; melanocytes; clear cell sarcoma

Human clear cell sarcoma (CCS) is a rare aggressive tumour, which is typically associated with tendons and aponeuroses and is thought to be of neuroectodermal origin (Chung and Enzinger 1983; Epstein et al, 1984). Clear cell sarcoma has also been called malignant melanoma of soft parts (MMSP) due to the occurrence of melanocytic markers and in some cases pigmentation (Epstein et al, 1984). Molecular studies of CCS have been limited due to the rarity of this malignancy and diagnostic problems prior to identification of the EWS/ATF1 oncogene as the definitive molecular signature of CCS.

EWS/ATF1 is created by aberrant $\mathrm{t}(12 ; 22)(\mathrm{q} 13 ; \mathrm{q} 12)$ chromosomal fusion (Zucman et al, 1993) of the Ewings Sarcoma oncogene (EWS) to the C-terminal region of activating transcription factor 1 (ATF1) . Activating transcription factor 1 is a bZIP protein that mediates cAMP-inducible transcription (Ribeiro et al, 1994), while in contrast EWS/ATF1 is a potent constitutive activator of CAMPinducible promoters (Brown et al, 1995; Fujimura et al, 1996; Pan et al, 1998; Feng and Lee, 2001); thus, suggesting that EWS/ATF1 may deregulate transcription of cAMP-inducible promoters in CCS cells. The physiological target promoters for EWS/ATF1 and their potential role in determining CCS biology and malignant

*Correspondence: Dr CR Goding; E-mail: c.goding@mcri.ac.uk transformation are beginning to be identified (Schaefer et al, 2002; Jishage et al, 2003). In addition to having a role in CCS genesis, EWS/ATF1 appears to be involved in CCS maintenance (Bosilevac et al, 1999) and may therefore be a therapeutic target.

The pigmentation that is sometimes associated with CCS suggests that ectopic expression of the melanocyte-inducing factor Mitf (microphthalmia-associated transcription factor; reviewed by Goding 2000) might be a key feature of CCS. Microphthalmiaassociated transcription factor exists in multiple isoforms (Mitf-A, Mitf-B, Mitf-C, Mitf-D, Mitf-H and Mitf-M) that are all members of the basic helix-loop-helix/leucine zipper (bHLH/LZ) family of transcription factors. The Mitf isoforms are highly related (Figure 3A), but contain unique $\mathrm{n}$-terminal exons expressed from distinct promoters (Udono et al, 2000, Figure 2A) that yield different expression profiles. The Mitf-M isoform is melanocyte specific and can induce melanocytic differentiation (Tachibana et al, 1996), indicating that Mitf-M is a critical melanogenic factor. Microphthalmia-associated transcription factor acts in part via direct transcriptional activation of genes (tyrosinase, TYRP1 and TYRP2) required for pigment synthesis (Bentley et al, 1994; Hemesath et al, 1994; Yavuzer et al, 1995; Yasumoto et al, 1997) and also has a role in melanocyte survival and differentiation (Lerner et al, 1986; Opdecamp et al, 1997; Hemesath et al, 1998). 
With respect to CCS, it is significant that transcription of the Mitf$\mathrm{M}$ isoform is controlled by a melanocyte-specific promoter (Fuse et al, 1996) that includes a cAMP-response element (CRE) comprising a single ATF1/CREB binding site (Bertolotto et al, 1998). Thus, the Mitf-M promoter is a potential target for EWS/ ATF1.

Limited attempts have been made to examine the Mitf-M expression in CCS. One study based on immunostaining of tumour specimens (Granter et al, 2001) concluded that Mitf is a marker for CCS, but did not confirm expression of the Mitf-M isoform due to detection method employed and use of the D5 Mitf-antibody (Hemesath et al, 1998) that recognises all Mitf isoforms. A second study detected Mitf-M RNA in nonviable CCS tumour material and did not examine Mitf-M protein expression (Antonescu et al, 2002). Here we show that Mitf-M mRNA and protein are expressed at significant levels in a wide range of CCS cell lines, demonstrating that Mitf-M is a stable marker for CCS in cell culture. In contrast, tyrosinase is not generally expressed in the CCS cells studied, indicating that elements of the pigmentation process downstream of Mitf are not stable in culture. Although the endogenous Mitf-M promoter is activated in CCS cells, the Mitf-M promoter is not active when transiently introduced into CCS cells or upon cotransfection with EWS/ATF1 in melanocytes or other cell types. Our results therefore indicate that Mitf-M promoter activation by EWS/ATF1 requires an appropriate chromosomal context in CCS cells or alternatively, that the Mitf-M promoter is not directly activated by EWS/ATF1.

\section{MATERIALS AND METHODS}

\section{Cell culture and cell lines}

All cell lines were maintained as monolayers in Dulbecco's modification of Eagle's medium (DMEM) containing 10\% FCS. Su-ccs-1 (Epstein et al, 1984), DTC1 (Brown et al, 1995), Kao (Hiraga et al, 1997), MST-1 (Liao et al, 1996) and GG-62 (Schaefer et al, 2002) cells have been described previously. All of the above cells (including MST-1, confirmed by detection of the EWS/ATF1 fusion transcript by rtPCR (Stella Chan and KL, unpublished results), MST-2 and MST-3 (S-K Liao, unpublished results) contain the $t(12 ; 22)$ translocation characteristic of CCS and express EWS/ ATF1 RNA. The expression of EWS/ATF1 protein in all of the above cell lines is shown here (Figure 1A).

\section{Plasmids and constructions}

$\mathrm{p} \Delta(-71)$ SomCAT contains the somatostatin promoter to position -71 , fused to the chloramphenicol acetyl transferase (CAT) coding sequences (Montminy et al, 1986). $\mathrm{p} \Delta(-42)$ SomCAT was obtained by digestion of $\mathrm{p} \Delta(-71)$ SomCAT with Aat2, blunting with T4 DNA polymerase and religation (Brown et al, 1995). pRSVCAT contains the RSV LTR linked to CAT as previously described (Gorman et al, 1982). pMITF-MCAT was obtained by insertion of CAT and MITF$\mathrm{M}$ promoter sequence from the position -395 into pSuppCT (Yavuzer and Goding, 1994). pMCRE contains two ATF sites from the MITF-M promoter upstream of the RSV TATA box and transcription site linked to CAT. pMCRE was obtained by insertion of an oligonucleotide containing tandem copies of the sequence (agcaTGACGTCAagccagg, the ATF site is underlined) between positions -151 and -133 of the MITF-M promoter into the Sac1 site of $\mathrm{p} \Delta \mathrm{ERSVCAT}$ (Tsukada et al, 1987). pMCREm corresponds to pMCRE containing mutated ATF sites (TGAtaTCA) that are unable to bind ATF1 (Jones and Lee, 1991). p $\Delta 287 \mathrm{C}$ has been described previously (Pan et al, 1998) and expresses a protein, containing the n-terminal 287 amino acids of EWS fused to ATF1, which is virtually identical to intact EWS/ATF1. pMMRP was obtained by insertion of an Nsi1/Hind3 fragment (from position
A
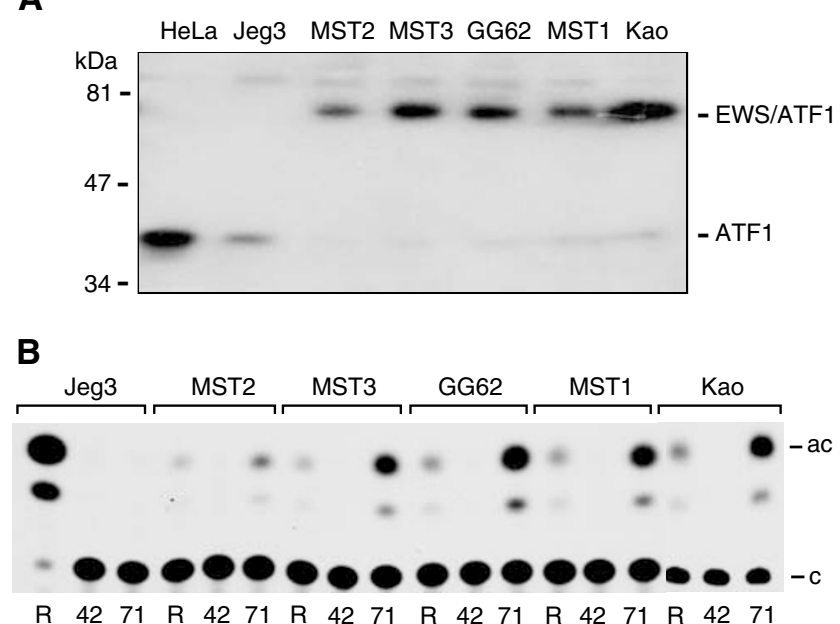

Figure I (A) Expression of EWS/ATFI in CCS cell lines. Proteins present in nuclear extracts from multiple CCS cell lines (MST-I, MST-2, MST-3, GG62 and Kao) or HeLa and Jeg3 negative control cells were purified by ATFI-sequence-specific DNA-affinity chromatography and subjected to Western blot analysis using anti-ATFI antibody. The ATFI and EWS/ATFI are indicated to the right and molecular weight standards (Biorad prestained, low molecular weight range) to the left. (B) ATF-sitedependent promoter activity in CCS cell lines. Transient transfection of CCS cell lines (indicated above) or leg3 control cells lacking EWS/ATF was performed using pRSVcat (R), $p \Delta(-7 \mathrm{I})$ SomCat containing a single ATF binding site (7I) or $\mathrm{p} \Delta(-42)$ SomCat lacking the ATF binding site (42). Transfection conditions were as described in the Materials and Methods and CAT assays were performed at $40 \mathrm{~h}$ post-transfection. A representative autoradiogram of a CAT assay is shown.

-50 to +136 of the MITF-M promoter) into Pst1/Hind3-digested pGem3.

\section{Transfections and reporter assays}

For CAT reporters, transfections were carried out by calcium phosphate coprecipitation and CAT assays were performed at $40 \mathrm{~h}$ post-transfection as previously described (Gorman et al, 1982). For promoter analysis, precipitates contained $5 \mu \mathrm{g}$ of reporter plasmid and $20 \mu \mathrm{g}$ of total DNA made up with pGem3 as carrier. For cAMPinduction, cells were cotransfected with reporter and $\mathrm{pCMVC} \alpha$ expressing the catalytic subunit of PKA and stimulated by addition of $300 \mu \mathrm{M}$ cptcAMP to the culture medium at $16 \mathrm{~h}$ posttransfection. For quantitation of results, percent conversion of unacetylated to acetylated ${ }^{14} \mathrm{C}$-chloramphenicol under linear assay conditions was determined by excision of spots from the TLC plate and quantitation of radioactivity using a liquid scintillation counter. For luciferase reporters, cells were transfected using Fugene reagent (Boehringer-Mannheim) according to the manufacturer's instructions and firefly luciferase activity was determined at $48 \mathrm{~h}$ post-transfection.

\section{RNA analysis}

For the RT-PCR, total RNA was reverse transcribed with AMV reverse transcriptase (Boehringer, Mannheim, Germany) followed by first-strand cDNA synthesis (Amersham cDNA synthesis kit) and PCR as described previously (Carreira et al, 1998). Reverse transcription - PCR analysis of Mitf-M was performed using MITF$M$ forward (5'ATGCTGGAAATGCTAGAATATAATC ${ }^{\prime}$ ) and reverse $\left(5^{\prime}\right.$ CAATCAGGTTGTGATTGTCC $\left.3^{\prime}\right)$ primers. For RNAse protection assays, preparation of total cellular RNA and detection 
of specific transcripts by RNAse protection analysis was performed as previously described. (Zinn et al, 1983). For detection of Mitf-M mRNA, pMMRP was linearised with $X b a 1$ and transcribed by SP6 RNA polymerase to produce a high specific activity ${ }^{32} \mathrm{P}$-labelled antisense probe (Figure 2A).

\section{Antibodies and western blotting}

For Western blotting, CREB antibody (New England Biolabs Beverly MA., Cat \#9192) was used at a 1:1000 dilution, ATF-1 antibody (Hurst et al, 1991] at 1:200 dilution, Mitf antibody (NeoMarkers Ab-1(C5)) at 1:500 dilution and tyrosinase antibody (C19, Santa Cruz, CA) for CREB (Amersham NA934) peroxidaseconjugated sheep anti-mouse (Amersham, NXA 931) for Mitf and peroxidase-conjugated anti-goat (Sigma, product \#A5420) for tyrosinase. ECL detection reagents (Amersham RPN2106) were used according to the manufacturer's instructions.

\section{Nuclear extracts and affinity purification}

Nuclear extracts were prepared as previously described (Hurst et al, 1990). For DNA affinity purification, $200 \mu \mathrm{l}$ of nuclear extract (derived from $\sim 10^{7}$ cells) was incubated at room temperature with $20 \mu \mathrm{l}$ of affinity resin (by resuspending the resin several times over a period of $30 \mathrm{~min}$ ) in the presence of $4 \mu \mathrm{g} \mathrm{ml}^{-1}$ poly [dI/dC]). After binding, the affinity resin was washed with two changes of buffer (20 mM HEPES pH 7.4; $100 \mathrm{~mm} \mathrm{KCl)} \mathrm{and} \mathrm{SDS} \mathrm{-} \mathrm{PAGE} \mathrm{sample}$ buffer was then added directly to the washed resin.

\section{RESULTS}

\section{Presence of EWS/ATF1 and ATF-site-dependent promoter activity in CCS cells}

A consistent $t(12 ; 22)(q 13 ; q 12)$ chromosomal translocation that produces the EWS/ATF1 fusion gene distinguishes CCS from cutaneous melanoma (van Roggen et al 1998). Several CCS cell lines have been established in culture and of these, Su-ccs-1 and DTC1 have been shown to express the EWS/ATF1 fusion protein (Brown et al, 1995). Several other cell lines used in this study (Kao, GG62, MST-2, MST-1 (see Materials and Methods) and MST-3) contain the EWS/ATF1 fusion gene, but have yet to be characterised for EWS/ATF1 protein expression. We tested for the presence of EWS/ATF1 in the above cell lines as previously described (Brown et al, 1995) by using ATF1 DNA-affinity purification of proteins present in nuclear extracts and detection by Western blotting using anti-ATF1 (Figure 1A). ATF1 is expressed at low levels in the CCS cells tested, while EWS/ATF1 (as indicated by an $\sim 80 \mathrm{kDa}$ polypeptide that binds to the ATF1 DNA affinity resin, reacts with a c-terminal ATF1 antibody and is absent in HeLa and Jeg3 cells) is detected at similar levels in all CCS cells tested.

We have previously shown that promoters that can be activated by EWS/ATF1 in a cotransfection assay are constitutively active when transiently introduced into CCS cells (Brown et al, 1995). For example, the somatostatin promoter $(\Delta(-71)$ SomCAT $)$ is highly active (260\% of RSVCAT) in DTC1 cells while exhibiting only background levels of activity $(0.03 \%$ of RSVCAT) in Jeg3 cells. Deletion of the ATF1 binding site in the somatostatin promoter $(\Delta(-42)$ SomCAT $)$ greatly reduces activity, strongly suggesting that endogenous EWS/ATF1 in CCS cells is responsible for high somatostatin promoter under the above conditions (Brown et al, 1995). To further characterise the additional CCS cells (Kao, GG62, MST1, MST-2 and MST-3) used here, we tested the ability of these to activate the $\Delta(-71)$ SomCAT reporter (Figure 1B). Similar to DTC1 and Su-ccs- 1 cells, $\Delta(-71)$ SomCAT was highly active (MST2, 285\% of RSVCAT; MST-3, 800\%; GG62, 860\%; MST1, 583\%;
$\mathrm{KAO}, 320 \%)$, while $\Delta(-42)$ SomCAT exhibited minimal activity in all of the above cell lines. In summary, the presence of similar levels of EWS/ATF1 and the ability to support constitutive ATFsite-dependent promoter activity indicates that the CCS cells described should be useful for transcriptional studies of EWS/ ATF1.

\section{Expression of Mitf-M RNA in CCS cells}

The Mitf gene is controlled by multiple promoters (Udono et al, 2000 , Figure 2A) that give rise to closely related but distinct isoforms (Mitf-A, Mitf-B, Mitf-C, Mitf-D, Mitf-H and Mitf-M, Figure $3 \mathrm{~A}$ ) that are distinguished by the presence of unique nterminal exons. The Mitf-M expression is restricted to neural crestderived melanocytes due to a melanocyte-specific promoter (Fuse et al, 1996), while the other Mitf isoforms are more broadly expressed. To probe for Mitf-M expression in CCS, we initially performed reverse transcription (RT) - PCR analysis of RNA from two CCS cell lines (DTC1 and Su-ccs-1) using Mitf-M-specific primers (Figure 2B). Microphthalmia-associated transcription factor-M RNA is readily detectable in DTC1 and Su-ccs-1 cells,

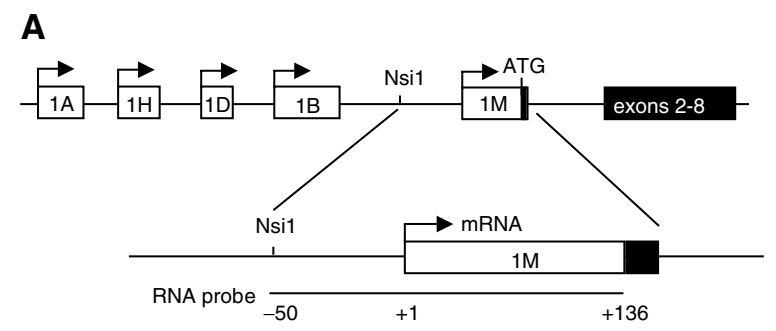

B
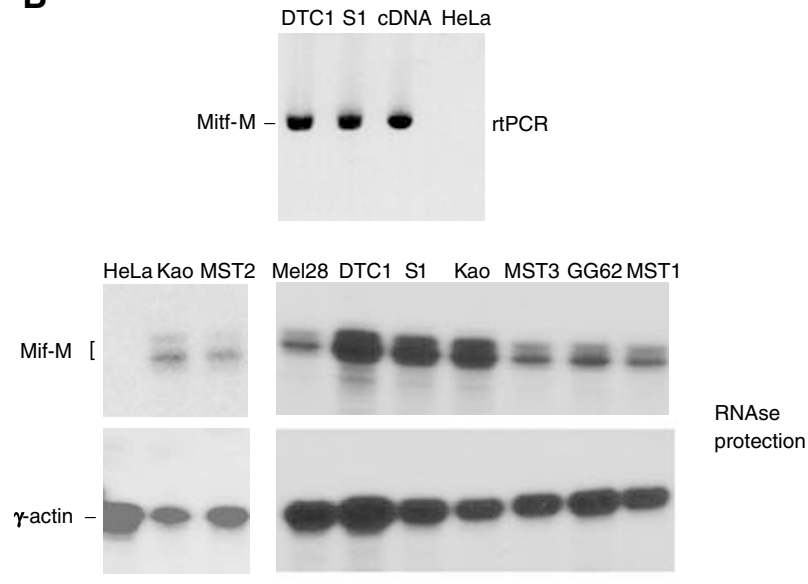

Figure 2 Analysis of Mitf-M RNA expression. (A) Structure of the human Mitf (hMitf) gene. The hMitf gene has alternative first exons (IA, $I \mathrm{H}, I D, I B$ and I M, shown in open boxes and IC, not shown or mapped) each containing a translation initiation codon, which arise from the use of five different promoters. Fusion of alternative first exons to common downstream exons 2-8 (black box) gives rise to distinct isoforms of Mitf (Mitf-A, Mitf-H, Mitf-D, Mitf-C, Mitf-B and Mitf-M) that differ only in their extreme n-terminal protein sequences. The Mitf-M promoter is melanocyte specific. (B) Detection of Mitf-M transcripts in CCS cells. Total RNA was extracted from the CCS cell lines indicated (SI ( Su-ccs-I)) and negative control (HeLa)) or positive control (Mel28) cells. RNA samples were analysed by RT-PCR (upper panel) or by RNAse protection assay (lower panel). microphthalmia-associated transcription factor-M isoform-specific primers used for RT-PCR analysis are described in Materials and Methods. ${ }^{32}$ P-labelled antisense probes for Mitf-M (shown in part A) and $\gamma$-actin as invariant control, were used for RNAse protection assays. Bands indicated to the left of the autoradiogram are the ${ }^{32} \mathrm{P}$-labelled protected fragments corresponding to correctly initiated Mitf-M and $\gamma$-actin mRNAs. 
A

\begin{tabular}{|c|c|c|c|c|}
\hline & & \multicolumn{2}{|c|}{ common } & \multirow[b]{2}{*}{409} \\
\hline A & B1b & S73 & bHLH-LZ & \\
\hline$C$ & $\mathrm{~B} 1 \mathrm{~b}$ & S73 & bHLH-LZ & S409 \\
\hline $\mathrm{H}$ & $\mathrm{B} 1 \mathrm{~b}$ & S73 & bHLH-LZ & S409 \\
\hline $\mathrm{D}$ & B1b & S73 & bHLH-LZ & S409 \\
\hline & $\mathrm{N}$ & S73 & & S409 \\
\hline
\end{tabular}

B
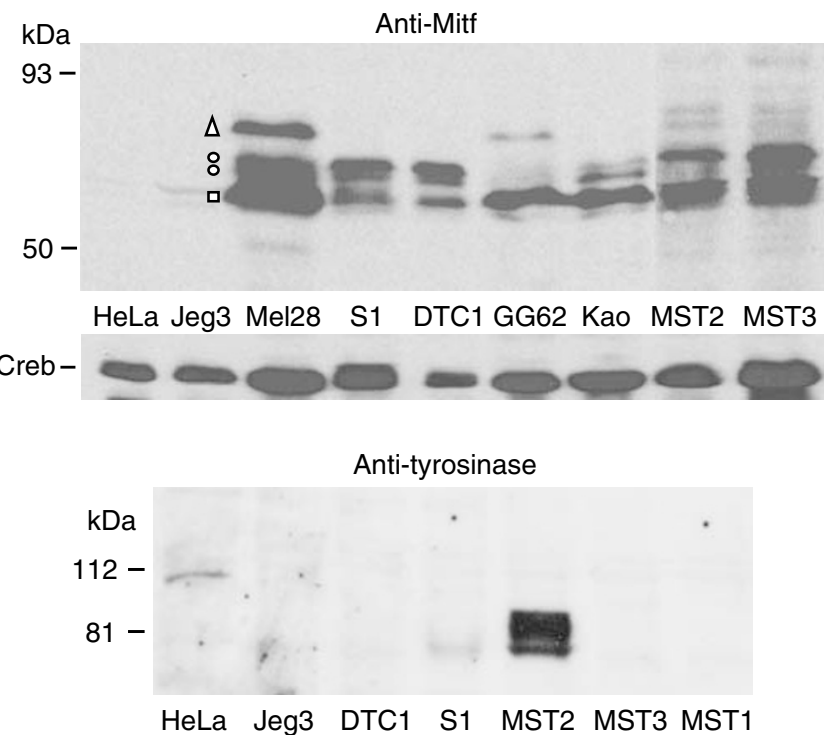

Figure 3 Expression of Mitf-M and tyrosinase proteins in CCS cells. (A) Structure of different isoforms of Mitf. White boxes represent the nterminal exons (including the translation initiation site) unique to each isoform and the grey box is common to all isoforms. The black box shows the position of the bHLH-LZ DNA binding and dimerisation domain of Mitf. S73 and S409 are serine phosphoacceptor sites for MAPK and Rsk-I, respectively. (B) Detection of Mitf and tyrosinase by Western blotting. For Mitf, whole-cell extracts from Mel28 cells (positive control), the CCS cells indicated or Jeg3 and HeLa cells (negative control) were analysed by Western Blotting using anti-Mitf antibody (NeoMarkers AB-I (C5)). Different Mitf isoforms are indicated by an open box, open circles and an open triangle adjacent to the Mel28 melanoma cell sample. Molecular weight standards ( $\mathrm{kDa}$, Biorad prestained low molecular weight range) are indicated to the left. The same samples were also probed with anti-CREB antibody (Cat \#9192, New England Biolabs) as a positive control. For tyrosinase, whole-cell extracts were probed with antityrosinase antibody (C19, Santa Cruz) and molecular weight standards (kDa, Biorad prestained low molecular weight range) are indicated to the left.

with HeLa cell RNA serving as a negative control (Figure 2B, top panel). We extended the analysis to several additional CCS cell lines and the pigmented melanoma cell line Mel28 (Carey et al, 1976) (as positive control) or HeLa cells (as negative control) using an RNAse protection assay (Figure $2 \mathrm{~B}$, bottom panel). Using a ${ }^{32} \mathrm{P}-$ labelled antisense probe spanning positions +136 to -50 of the Mitf-M promoter (Figure 2A), protected fragments of $\sim 136 \mathrm{nt}$ representing correctly initiated Mitf-M transcripts are observed in Mel28 cells but not in HeLa cells (as expected) and are observed in all CCS cell lines tested at levels similar to Mel28. Considering the structure of the Mitf gene (Figure 2A), the above result indicates that the Mitf-M promoter is active in CCS cells.

\section{Expression of Mitf-M protein in CCS cells}

Following detection of Mitf-M RNA, we performed Western blotting to examine expression of Mitf proteins in CCS cells compared with Mel28 cells (Figure 3). We used a monoclonal antibody (C5) that detects all Mitf isoforms (Figure 3A) and that has been extensively used for studies of Mitf-M (Bertolotto et al, 1998; King et al, 1999; King et al, 2001; Wu et al, 2000). In Mel28 cells, the C5 antibody detects four polypeptides within the reported size range of Mitf $(55-75 \mathrm{kDa}$, Figure $3 \mathrm{~B})$ and these polypeptides are absent or expressed at very low levels in nonmelanoma cells (HeLa and Jeg3). The above pattern is consistent with (but more complex than) other studies using melanoma cells and the C5 antibody (Bertolotto et al, 1998; King et al, 1999; Wu et al, 2000) or another antibody (D5) (Hemesath et al, 1998) in which an $\sim 55-60 \mathrm{kDa}$ Mitf-M doublet is detected. Several considerations indicate that in Mel28 cells, either the fastest migrating polypeptide (indicated by an open box in Figure $3 \mathrm{~B}$ ) or the slower migrating doublet (open circles, Figure $3 \mathrm{~B}$ ) or both of the above, are Mitf-M. First, Mitf-M is significantly smaller than all other Mitf isoforms (Figure 3A) and migrates faster in SDS gels at around $55-60 \mathrm{kDa}$ (Fuse et al, 1999). Thus, if the polypeptides detected in Mel28 cells are different Mitfisoforms, the fastest migrating polypeptide(s) in the range of 55$60 \mathrm{kDa}$ are Mitf-M. Second, Mitf-C (Fuse et al, 1999), Mitf-D (Takeda et al, 2002) and Mitf-H (Amae et al, 1998) are reportedly not expressed in melanoma cells. The slowest migrating polypeptide in Mel28 cells (open triangle, Figure 3B) is consistent with the size of the more widely expressed Mitf-A isoform (Fuse et al, 1999). Significantly, with respect to the presumptive Mitf-M isoforms in Mel28 cells (open box and/or open circles), the C5 antibody detected a similar but not identical pattern of polypeptides in all CCS cell lines (see discussion). Although we cannot unequivocally assign Mitf-M to a particular band(s), based on the considerations above, we conclude that Mitf-M (or isoforms thereof) is expressed at significant levels in all CCS cell lines tested. Moreover, unless there is translational control of Mitf-M, the above result is expected based on the significant levels Mitf-M RNA transcripts in all of the CCS cells studied (Figure 2B).

Microphthalmia-associated transcription factor-M functions in melanocyte differentiation and survival, and directly activates the promoters of genes, including tyrosinase, that are required for pigment production (Bentley et al, 1994; Hemesath et al, 1994; Yavuzer et al, 1995; Yasumoto et al, 1997). To evaluate the downstream effects of Mitf-M expression in CCS cells, we surveyed expression of tyrosinase (Figure 3B, bottom panel) by Western blotting (using tyrosinase antibody C19, Santa Cruz, CA.). Strikingly, tyrosinase was expressed at significant levels in only one cell line (MST-2) and was either very weakly expressed (Succs-1 and Kao (data not shown)) or was undetectable (DTC1, MST1 and MST-3) in other CCS cell lines. This result is consistent with a striking pigmentation that is visible with the naked eye for MST2 cells (KAWL, unpublished observations). In summary, our results show that while Mitf-M is consistently and stably expressed in CCS cell lines in culture, pigmentation, as scored by tyrosinase expression, is generally not preserved.

\section{Activity of the Mitf-M promoter in CCS cells}

All CCS cell lines used in our study are able to support high levels of constitutive ATF-site- dependent promoter activity in a transient transfection assay (Figure 1B). We used the above assay to ask whether the Mitf-M promoter (pMITF-MCAT) can be activated in CCS cells (Figure 4A). Surprisingly, however, pMITFMCAT exhibited near background levels of activity in DTC1, Kao, MST-2 and MST-3 cells, indicating that endogenous EWS/ATF1 is unable to activate a transiently introduced Mitf-M promoter in CCS cells. To test directly the ability of EWS/ATF1 to activate the 
A

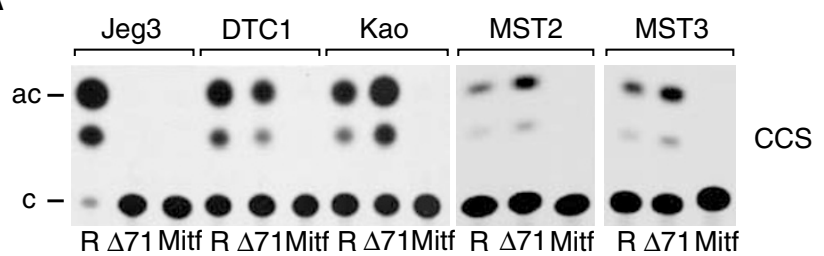

B

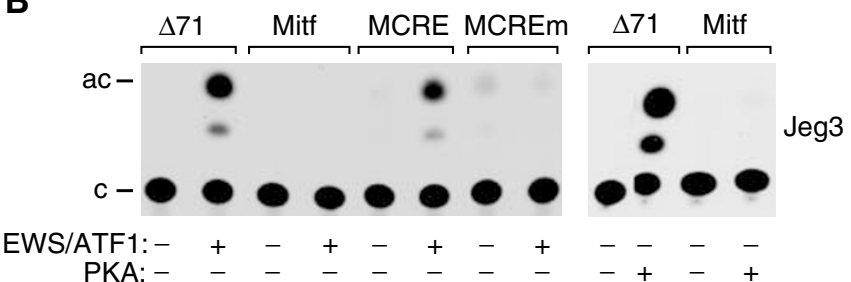

C

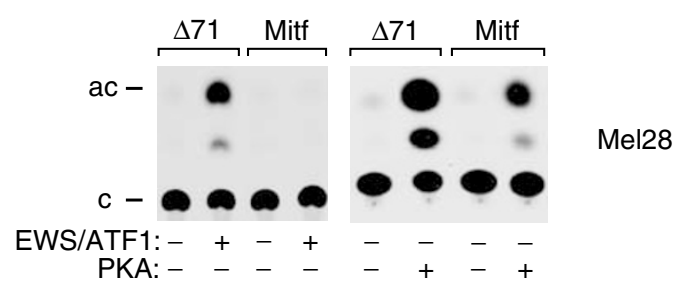

Figure 4 Mitf-M promoter analysis. (A) Mitf-M promoter activity in CCS cell lines. The CCS cell lines indicated or Jeg3 cells as control were transfected with pRSVCAT $(\mathrm{R}), \Delta(-7 \mathrm{I})$ SomCAT $(\Delta 7 \mathrm{I})$ or pMITF-MCAT (Mitf). (B) Transactivation by EWS/ATFI and PKA in Jeg3 cells. Cell were transfected with the reporter plasmids $(\mathrm{p} \Delta(-7 \mathrm{I})$ SomCAT $(\Delta 7 \mathrm{I})$, PMITFMCAT (Mitf), PMCRECAT (MCRE) and pMCREmCAT (MCREm)) indicated above in the absence $(-)$ and presence $(+)$ of $\mathrm{p} \triangle 287 \mathrm{C}$ expressing EWS/ATFI or PCMVC $\alpha$ expressing the catalytic subunit of PKA. (C) Transactivation by EWS/ATFI and PKA in melanoma cells. Mel 28 cells were transfected with the reporter plasmids $(\mathrm{p} \Delta(-7 \mathrm{I})$ SomCAT $(\Delta 7 \mathrm{I})$ and pMITF-MCAT (Mitf)) indicated above in the absence $(-)$ and presence $(+)$ of $p \Delta 287 C$ expressing EWS/ATFI or $\mathrm{pCMVC} \alpha$ expressing the catalytic subunit of PKA.

Mitf-M promoter, we used a previously described transient cotransfection assay in which ATF-dependent promoters (including $\mathrm{p} \Delta(-71)$ SomCat $)$ are strongly activated by exogenous EWS/ ATF1 (Brown et al, 1995). Similar to the above result in CCS cells, exogenous EWS/ATF1 (expressed from $\mathrm{p} \Delta 287 \mathrm{C}$ ) is unable to activate the Mitf-M promoter in either Jeg3 cells (Figure 4B) or the melanoma cell line Mel28 (Figure 4C) in which the Mitf-M promoter is normally active. As a positive control for the integrity of the Mitf-M reporter, pMITF-MCAT is able to exhibit a melanocyte-specific cAMP-response in Mel28 cells (Figure 4B and C) as expected (Bertolotto et al, 1998). Finally, we tested the ability of the ATF binding site in the Mitf-M promoter to confer EWS/ATF1 responsiveness to a heterologous promoter in Jeg3 cells (Figure 4C). pMCRE contains tandem ATF sites from the Mitf-M promoter placed upstream of the RSV TATA box and is activated by EWS/ATF1, while mutations that eliminate ATF1 binding (pMCREm) also eliminate response to EWS/ATF1. Similar results are obtained in melanoma 501-Mel cells upon fusion of the Mitf-M CRE to the tk promoter (data not shown). Taken together, the above results using transient transfection assays demonstrate that the Mitf-M ATF binding site can confer response to EWS/ATF1 but that surprisingly, the Mitf-M promoter is refractory to EWS/ATF1, even under conditions (in melanocytes) in which the Mitf-M promoter is amenable to activation by cAMP.

\section{DISCUSSION}

The ability of Mitf to induce melanocytic or pigmented features in other cell types (Tachibana et al, 1996; Planque et al, 1999) suggests that the occurrence of such features in CCS arises due to ectopic expression of Mitf-M. Consistent with this idea, Mitf-M transcripts have been detected in nonviable tumour specimens by RT-PCR (Antonescu et al, 2002), indicating that Mitf-M RNA can serve as a diagnostic marker for CCS. Here, we report that the Mitf$M$ promoter is active and the Mitf-M protein is expressed in several cultured CCS cells. Our results therefore establish a panel of cell lines that provide a valuable experimental resource for studies of CCS and the role of Mitf-M in cellular differentiation and survival. In contrast to Mitf-M, tyrosinase expression is not generally maintained (MST-2 cells are an exception although even in this case, tyrosinase levels are greatly reduced following prolonged culture (KAWL, unpublished observations)). The above results are also similar to those observed in melanoma, whereby amelanotic tumour samples remain positive for Mitf (King et al, 1999).The apparent absence of tyrosinase in our experiments is consistent with earlier studies of most CCS cell lines (Epstein et al, 1984; Sonobe et al, 1993; Liao et al, 1996; Hiraga et al, 1997), which are only weakly melanotic. In light of our results, the absence of tyrosinase expression in cultured CCS cells is notable, since the tyrosinase promoter is a direct target for Mitf-M in melanoma cells (Bentley et al, 1994; Yasumoto et al, 1994). The observation that exogenous Mitf-M fails to reactivate the tyrosinase promoter in melanoma cells that have lost expression of Mitf-M (Vachtenheim et al, 2001) suggests that Mitf-M might, likewise, not be able to activate the tyrosinase promoter in CCS cells. Alternatively, degradation of tyrosinase protein similar to that which occurs in amelanotic melanoma (Halaban et al, 1997) might explain lack of tyrosinase in cultured CCS cells. The above possibilities remain to be examined.

As we have described in the results section, lack of an Mitf-Mspecific antibody precludes an unequivocal assignment of Mitf-M among the polypeptides detected in our Western blot analysis (Figure 3B). We note however that dual phosphorylations of Mitf$M$ by c-kit induced MAP kinase (on S73) and Rsk-1 (on S409) dramatically affect the mobility of Mitf-M on SDS gels and the stability of Mitf-M (Wu et al, 2000; Xu et al, 2000). Specifically, phosphorylation of either S73 or S409 alone accounts for the 55$60 \mathrm{kDa}$ Mitf-M doublet reported in other studies (Hemesath et al, 1998; Wu et al, 2000; Xu et al, 2000) and an unphosphorylatable S73A/S409A Mitf-M double mutant is greatly stabilised and migrates faster than the $55-60 \mathrm{kDa}$ doublet (Wu et al, 2000). Moreover, the relative levels of Mitf-M phosphovariants differ widely in different melanoma cells (King et al, 1999), presumably reflecting variation in the MAP/Rsk-1 signalling status. Taking the above observations together, it seems quite possible that in CCS cells, the fastest migrating polypeptide (Figure 3B, open box) and the slower migrating doublet (Figure $3 \mathrm{~B}$, open circles) are all phosphovariants of Mitf-M, and that the differential pattern of bands observed in CCS reflects variations in endogenous signalling pathways in the different CCS cells examined.

Our results raise the possibility that Mitf-M is involved in CCS tumorigenesis. The maintenance of Mitf-M expression may reflect a selection process that indicates a role for Mitf-M in CCS cell survival. In this respect, it is pertinent that Mitf-M functions in normal melanocyte survival (Opdecamp et al, 1997) by mediating c-Kit signalling (Hemesath et al, 1998). The expression of Mitf-M may sensitise CCS cells to a c-Kit/MAP kinase signalling pathway in a manner that contributes to their malignant character. It will be of interest to manipulate Mitf-M expression in CCS cells and examine the effects on cell growth/survival and tumorigenicity in nude mice. If Mitf-M is required for maintenance of CCS tumorigenicity, restricted expression of Mitf-M indicates that it represents a potential therapeutic target for CCS. 
While expression of Mitf-M in CCS suggests that EWS/ATF1 may activate the Mitf-M promoter, we have been unable to demonstrate this directly. Our results are equally consistent with either of two possibilities. Firstly, despite the fact that EWS/ATF1 is able to bind to the Mitf-M CRE and activate transcription when out of context (Figure 4), it may simply be the case that EWS/ATF1 is not directly responsible for activation of the endogenous Mitf-M promoter in CCS cells. The inability of EWS/ATF1 to activate the Mitf-M promoter in melanocytes, under conditions in which the promoter is amenable to activation by cAMP (Figure 4), supports this idea. Another alternative is that lack of EWS/ATF1 responsiveness in transient assays might reflect a requirement for an appropriate chromatin context of the Mitf-M promoter. The ability of the Mitf-M ATF binding site per se to confer response to EWS/ ATF1 in a heterologous promoter context suggests that other transcription factors, including Pax 3, Sox10 and Lef1 that are known to directly regulate the Mitf-M promoter (reviewed in Goding, 2000), might cooperate with EWS/ATF1 to activate the chromosomal Mitf-M promoter in CCS cells.

\section{ACKNOWLEDGEMENTS}

We are grateful to $\mathrm{Dr} F$ van Valen of the Laboratory for Experimental Orthopaedic Research (LEOR), Muenster, Germany for generation of the GG-62 cell line. This work was supported by Hong Kong SAR Government Research Grants Council grant (award \#HKUST 6128/99M) to KAWL by a grant from the National Science Council of Taiwan (NSC-0412B82-096) to S-KL and by Marie Curie Cancer Care.

\section{REFERENCES}

Amae SN, Fuse K, Yasumoto K, Sato S, Yajima I, Yamamoto H, Udono T, Durlu YK, Tarnai M, Takahashi K, Shibahara S (1998) Identification of a novel isoform of the microphthalmia-associated transcription factor that is enriched in retinal pigment epithelium. Biochem Biophys Res Commun 247: $710-715$

Antonescu CR, Tschemyavsky SJ, Woodruff JM, Jungbluth AA, Brennan MF, Ladanyi M (2002) Molecular diagnosis of clear cell sarcoma. Detection if EWS-ATF1 and MITF-M transcripts and histopathologic and ultrastructural analysis of 12 cases. J Mol Diagn 4: 44-52

Bentley NJ, Eisen T, Goding CR (1994) Melanocyte-specifc expression of the human tyrosinase promoter: activation by the microphthalmia gene product melanoma cells. Proc Natl Acad Sci USA 94: 6210-6215

Bertolotto C, Abbe P, Hemesath TJ, Bille K, Fisher DE, Ortonne JP, Ballotti $\mathrm{R}$ (1998) Microphthalmia gene product as a signal transducer in cAMPinduced differentiation of melanocytes. J Cell Biol 142: $827-835$

Bosilevac JM, Olsen RJ, Bridge JA, Hinrichs SH (1999) Tumor cell viability in clear cell sarcoma requires DNA binding activity of the EWS/ATF1 fusion protein. J Biol Chem 274: 34811-34818

Brown AD, Lopez-Terrada D, Denny CT, Lee KAW (1995) Promoters containing ATF-binding sites are de-regulated in cells that express the EWS/ATF1 oncogene. Oncogene 10: 1749-1756

Carey TE, Takahashi T, Resnick LA, Oettgen HF, Old LJ (1976) Cell surface antigens of human malignant melanoma: mixed hemadsorption assays for humoral immunity to cultured autologous melanoma cells. Proc Natl Acad Sci USA 73: 3278-3282

Carreira S, Dexter TJ, Yavuzer U, Easty DJ, Goding CR (1998) Brachyuryrelated transcription factor $\mathrm{Tbx} 2$ and repression of the melanocyticspecific TRP-1 promoter. Mol Cell Biol 18: 5099-5108

Chung EB, Enzinger FM (1983) Malignant melanoma of soft parts. A reassessment of clear cell sarcoma. Am J Surg Pathol 7: 405-413

Epstein AL, Martin AO, Kempson R (1984) Use of a newly established human cell line (SU-CCS-1) to demonstrate the relationship of clear cell sarcoma to malignant melanoma. Cancer Research 44: 1265-1274

Feng L, Lee KAW (2001) A repetitive element containing a critical tyrosine residue is required for transcriptional activation by the EWS/ATF1 oncogene. Oncogene 20: $4161-4168$

Fuse N, Yasumoto K-I, Suzuki H, Takahashi K, Shibahara S (1996) Identification of a melanocyte-type promoter of the microphthalmiaassociated transcription factor gene. Biochem Biophys Res Comm 219: $702-707$

Fuse N, Yasumoto K-I, Takeda K, Amae S, Yoshizawa M, Udono T, Takahashi K, Tamai M, Tomita Y, Tachibana M, Shibahara S (1999) Molecular cloning of cDNA encoding a novel microphthalmia-associated transcription factor isoform with a distinct amino terminus. J Biochem 126: $1043-1051$

Fujimura Y, Ohno T, Siddique H, Lee L, Rao VN, Reddy ESP (1996) The EWS-ATF-1 gene involved in malignant melanoma of soft parts with $t$ $(12 ; 22)$ chromosome translocation, encodes a constitutive transcriptional activator. Oncogene 12: 159-167

Goding CR (2000) Mitf from neural crest to melanoma: signal transduction and transcription in the melanocyte lineage. Genes Dev 14: 1712-1728

Gorman CM, Merlino GT, Willingham MC, Pastan I, Howard BH (1982) The Rous sarcoma virus long terminal repeat is a strong promoter when introduced into a variety of eukaryotic cells by DNA-mediated transfection. Proc Natl Acad Sci USA 79: 6777-6781

Granter SR, Weilbaecher KN, Quigley C, Hetcher CDM, Fisher DE (2001) Clear cell sarcoma shows immunoreactivity for microphthalmia transcription factor: further evidence for melanocytic differentiation. Mod Pathol 14: 6-9

Halaban R, Cheng E, Zhang Y, Moellmann G, Hanlon D, Michalak M, Setaluri M, Hebert D (1997) Aberrant retention of tyrosinase in the endoplasmic reticulum mediates accelerated degradation of the enzyme and contributes to the dedifferentiated phenotype of amelanotic melanoma cells. Proc Natl Acad Sci USA 94: 6210-6215

Hemesath TJ, Price ER, Takemoto C, Badalian T, Fisher DE (1998) MAP kinase links the transcription factor microphthalmia to c-Kit signalling in melanocytes. Nature 391: 298-301

Hiraga $H$, Nojima $T$, Abe S, Yamashiro K, Yamawaki S, Kaneda K, Nagashima K (1997) Establishment of a new continuous clear cell sarcoma cell line. Virch Arch 431: 45-51

Hurst HC, Masson N, Jones NC, Lee KAW (1990) The cellular transcription factor CREB corresponds to activating transcription factor 47 (ATF-47) and forms complexes with a group of polypeptides related to ATF-43. Mol Cell Biol 10: 6192-6203

Hurst HC, Totty NF, Jones NC. (1991) Identification and functional characterisation of the cellular activating transcription factor 43 (ATF43). Nucleic Acids Res 19: $4601-4609$

Jishage M, Fujino T, Yamazaki Y, Kuroda H, Nakamura T (2003) Identification of target genes for EWS/ATF1 chimeric transcription factor. Oncogene 22: $41-49$

Jones C, Lee KAW (1991) E1A-mediated activation of the adenovirus E4 promoter can occur independently of the cellular transcription factor E4F. Mol Cell Biol 11: 4297-4305

King R, Googe PB, Weilbaecher KN, Mihm MC, Fisher DE (2001) Microphthalmia transcription factor expression in cutaneous benign, malignant melanocytic, and non-melanocytic tumors. Am J Surg Pathol 25: $51-57$

King R, Weilbaecher KN, McGill G, Cooley E, Mihm MC, Fisher DE (1999) Microphthalmia transcription factor. A sensitive and specific melanocyte marker for melanoma diagnosis. Am J Pathol 155: $731-738$

Lerner AB, Shibahara T, Boissy RE, Jacobson KA, Lamoreux ML, Moellmann GE (1986) A mouse model for vitiligo. J Invest Dermatol 87: $299-304$

Liao SK, Perng YP, Lee LA, Chang KSS, Lai GM, Wong E, Ho YS (1996) Newly established MST-1 tumour cell line and tumor-infiltrating lymphocyte culture from a patient with soft tissue melanoma (clear cell sarcoma) and their potential applications to patient immunotherapy. Eur J Cancer 32: $346-356$

Montminy MR, Sevarino KA, Wagner JA, Mandel G, Goodman RH (1986) Identification of a cyclic AMP-responsive element within the rat somatostatin gene. Proc Natl Acad Sci USA 86: 6682-6686

Opdecamp K, Nakayama A, Nguyen MT, Hodgkinson CA, Pavan WJ, Arnheiter H (1997) Melanocyte development in vivo and in neural crest cell cultures: crucial dependence on the Mitf basic-helix-loop-helix transcription factor. Development 124: $2377-2386$ 
Pan S, Ming KY, Dunn TA, Li KKC, Lee KAW (1998) The EWS/ATF1 fusion Protein contains a dispersed activation domain that functions directly. Oncogene 16: $1625-1631$

Planque N, Turque N, Opdecamp K, Bailly M, Martin P, Saule S (1999) Expression of the microphthalmia-associated basic helix-loop-helix leucine zipper transcription factor $\mathrm{Mi}$ in avian neuroretina cells induces a pigmented phenotype. Cell Growth Differ 10: 525-536

Ribeiro A, Brown AD, Lee KAW (1994) An in vivo assay for members of the cAMP-response element-binding protein family of transcription factors J Biol Chem 269: $31124-31128$

Schaefer KL, Wai DH, Poremba C, Korsching E, van Valen F, Ozaki T, Boecker W, Dockhorn-Dworniczak B (2002) Characterization of the malignant melanoma of soft parts cell line GG-62 by expression analysis using DNA microarrays. Virch Arch 440: 476-484

Sonobe H, Furihata M, Iwata J, Ohtsuki Y, Mizobuchi H, Yamamoto H, Kumano O (1993) Establishment and characterisation of a new human clear cell sarcoma cell line, HS-MM. J Pathol 169: 317-322

Tachibana M, Takeda K, Nobukuni Y, Urabe K, Long JE, Meyers KA, Aaronson SA, Miki T (1996) Ectopic expression of MITF, a gene for Waardenburg syndrome type 2, converts fibroblasts to cells with melanocyte characteristics. Nat Genet 14: $50-54$

Takeda K, Yasumoto K-I, Kawaguchi N, Udono T, Watanabe K-I, Saito H, Takahashi K, Noda M, Shibahara S (2002) Mitf-D, a newly identified isoform, expressed in the retinal pigment epithelium and monocyte lineage cells affected by Mitf mutations. Biochim Biophys Acta 1574: 15 23

Tsukada T, Fink JS, Mandel G, Goodman RH (1987) Identification of a region in the human vasoactive intestinal polypeptide gene responsible for regulation by cyclic AMP. J Biol Chem 262: 8743-8747

Udono T, Yasumoto K, Takeda K, Amae S, Watanabe K, Saito H, Fuse N, Tachibana M, Takahashi K, Tamai M, Shibahara S (2000) Structural organization of the human microphthalmia-associated transcription factor gene containing four alternative promoters. Biochim Biophys Acta 1491: $205-219$
Vachtenheim J, Novotna H, Ghanem G (2001) Transcriptional repression of the microphthalmia gene in melanoma cells correlates with the unresponsiveness of target genes to ectopic microphthalmia-associated transcription factor. J Invest Dermatol 117: 1505-1511

van Roggen JFG, Mooi WJ, Hogendoorn PCW (1998) Clear cell sarcoma of tendons and aponeuroses (malignant melanoma of soft parts) and cutaneous melanoma: exploring the histogenetic relationship between these two clinicopathologic entities. J Pathol 186: $3-7$

Wu M, Hemesath TJ, Takemoto CM, Horstmann MA, Wells AG, Price ER Fisher DZ, Fisher DE (2000) c-Kit triggers dual phosphorylations which couple activation and degradation of the essential melanocyte factor $\mathrm{Mi}$. Genes Dev 14: $301-312$

Xu W, Gong L, Haddad MM, Bischof O, Campisi J, Yeh ET, Medrano EE (2000) Regulation of microphthalmia-associated transcription factor MITF protein levels by association with the ubiquitin-conjugating enzyme hUBC9. Exp Cell Res 255: 135-143

Yavuzer U, Goding CR (1994) Melanocyte-specific gene expression: the role of repression and the identification of a melanocyte-specific factor MSF. Mol Cell Biol 14: 3494-3503

Yavuzer U, Keenan E, Lowings P, Vachtenheim J, Currie G, Goding CR (1995) The microphthalmia gene product interacts with the retinoblastoma protein in vitro and is a target for deregulation of melanocytespecific transcription. Oncogene 10: $123-134$

Yasumoto, K-I, Yokoyama K, Takahashi K, Tomita Y, Shibahara S (1997) Functional analysis of microphthalmia-associated transcription factor in pigment cell-specific transcription of the human tyrosinase family genes. J Biol Chem 272: 503-509

Zinn K, DiMaio D, Maniatis T (1983) Identification of two distinct regulatory regions adjacent to the human $\beta$-interferon gene. Cell 34 $865-879$

Zucman J, Delattre, Desmase C, Epstein AL, Stenman G, Speleman F, Fletcher CDM, Aurias A, Thomas G (1993) EWS and ATF-1 gene fusion induced by $\mathrm{t}(12 ; 22)$ in malignant melanoma of soft parts. Nat Genet 4: $341-345$ 